\title{
Portuguese Diaspora: Life Stories / Documentaries
}

\author{
Maria Helena Padrão \\ (helenapadrao@hotmail.com) \\ ISMAI, Instituto Universitário da Maia \\ CELCC-CIAC \\ Inês Guerra \\ ISMAI, Instituto Universitário da Maia \\ CELCC-CIAC \\ Joana Padrão \\ USC-ES \\ Isidro, João \\ ISMAI, Instituto Universitário da Maia
}

DOI:10.5901/mjss.2014.v5n22p533

\begin{abstract}
The return is a change that is configured at various levels - relationships, routines, roles - and can interfere with the self concept and the concept that individuals have about the other. (Schlossberg, Waters \& Goodman, 1995). The mobility in this case the return is a transition and / or a crisis in that the individual initiates an adaptation process. This process is influenced by several variables, including the subjective perception regarding the event and the different characteristics of the contexts of exit and reception and the characteristics of the actors in this event. (Pine and Ferreira, 2002; Evans \& Forney , Guido DiBrito , 1998). If migrations occur regularly, this process can not interferewithf the return movement of the Portuguese diaspora since decolonization that constituted for the Portuguese a transition not expected and, but configuring contexts breakthrough. The intention is to understand the contexts of life of the people involved in the process ( rupture, integration , opportunities, etc. ) through the documentaries made for the purpose.
\end{abstract}

Keywords: Return; Portuguese; Diaspora; Self-concept; Life stories

\section{Introduction}

Migratory movements have been a constant in human history. In this case Portuguese population mobility persisted for centuries as one of the main responsible for the increasing mixing of cultures.

Associated with the epic of the discoveries, the Portuguese emigration was for centuries characterized by massive outflows of Portuguese population to newly discovered territories (Duverger, 1994). One of the most striking phenomena of the 70s in Portugal was the return of half a million residents in the former Portuguese colonies.

From a theoretical point of view we find different approaches to the phenomenon of emigration. Thus, a neo-liberal perspective (supported on the assumptions of neo-classical theory of rational individual choice) migratory movements are essentially the result of personal decisions resulting from a comparative analysis of the advantages and disadvantages associated. In turn, from a materialistic perspective, Marx interrelates the role of migration to the phenomenon of population growth, but believes that emigration does not result directly from demographic factors but the unequal distribution of capital.

Regarding the level of integration, Chiswick (2002) suggests that the degree of integration of immigrant in the new society depends primarily on its ability to acquire knowledge putting it at the same professional level of national workers (which in reality does not always happen).

In this study, the analysis is based on interviews with a number of Portuguese who returned from Africa shortly after the April 25, 1974, and to whom the Portuguese society dubbed, so even the "returnees". 
The term "returned" appears to refer to those who "return" from the former colonies and encloses a racial criterion in that it refers to the white population of Africa (Pena Pires, 2003:227). From a legal and political point of view, the condition of "returned" is attributed to him that keeping his Portuguese citizenship, has resided in the former colonies.

Although the official number of Portuguese who "returned" from Africa for the former metropolis is unknown, it is expected that it will be between five hundred thousand and one million individuals (cf. Carrington and Lima 1996; Pena Pires: 1984 2003; Rocha-Trindade: 1995).

Given the kind of research we intend to do, it appealed mainly to life stories and collecting photographs since the parallel study being presented here is a video produced to support the interviews being analysed and some images of that period.

A comparison of reports allows us to present these subjects as protagonists of a story with many points in common. The memories that intersect, allow us to associate certain concepts to emigration and how the whole process of Portuguese decolonization was carried out. These commonalities despite different experiences, let us say that this is "a group" that has acquired a kind of identity.

In addition to the identity issues and their intergenerational reflexes, a central issue in this analysis is integration, not only economic but above all social and cultural. Indeed a phenomenon that seems applicant in migration (regardless of destination) is that immigrants, on arrival at the destination country feel as a "strange" element and after the return they have the same feeling about the country they left which is, necessarily, different now.

\section{The social integration of returnees: experiences, representations and identity.}

In the years that followed the 25th April 1974 revolution, was recorded in Portugal, an exodus with the arrival at Lisbon an endless number of returnees.

While some of them have made scale in South Africa or Rhodesia or has chosen to take refuge in Brazil, the great majority of returnees chose Metropolis as a destination.

Pires (1984), based on 1981 Census data highlight a set of characteristics of the returned population: nearly two-thirds were from Angola, more than three-quarters were in 1981, aged 15 years old and natural colonies, about half of them were aged between 15 and 39 years old, 60\% born in Portugal, the majority was natural urban centres of Lisbon or Porto and Northern or Central interior.

Literature stresses the importance of second-generation returnees because cultural differences seem even more evident. Another important aspect relates to the fact that the colonies attract people with higher qualifications in contrast with the European migration. There are indeed significant differences between the Portuguese emigration to Europe and the former colonies particularly with regard to how the Portuguese saw the return to the home country. One respondent refers precisely this difference noting that "We were some gentlemen who lived well there, with five set to make the bed, the other five for the garden, and those who went to France went to work on building ... so it is the big difference "(...)" to Angola and Mozambique emigrated not only very needy people, not only workers ... who emigrated ... the great impact of our emigration to Africa was given by major economic groups." (E1).

About the resident population, we don't knew almost anything. This lack worsened the relationship between the two groups and contributes significantly to the deterioration of the image of the "returned" that in the field of social representations, now, in many cases, be seen as a threat to economic and social conditions of those who have always remained in the country.

Social representations refer to knowledge or common sense theories. Its spread in the media, in familiar conversations on the Internet, provides a collective or social character, as Moscovici (2001) says. At the same time, presenting a mixture of images and concepts are merged, inaccurate and without much coherence or rationality (still arriving even to the point of evoking a presumed scientific). However, as the author points out, the communities do not work without social representations. They guide the behaviours and confer legitimacy.

However, even though the word "returned" shut itself a stigma, the integration of these persons unless exceptional and dramatic cases of non-integration was relatively easy because even most adults returned were from Portugal where they held family. So maybe also the most common is the return "to their homeland", which is why most returnees have returned to areas where they were born and / or where their families lived. 
This does not mean, however, that the criterion for inclusion / non-inclusion in the labour market has not been important in fixing. Pires (2003) also puts forward another possible reason for the relative ease of integration of returnees in Portuguese society: this is to be processed during a period in which they occurred in Portuguese society several economic and cultural transformations that may have favoured the integration professional returnees and provided a climate of greater cultural openness.

Since the object of this study are " the returned" from overseas colonies and the main objective is to analyse how they have done their integration in the Metropolis (detecting particular intergenerational differences), we analysed four interviews (a significantly larger) group in order to collect the experiences of individuals who, by their experience of life, participated in the story which we intend to present now.

The comparative analysis of the interviews shows individuals protagonists of a story with many points in common and therefore with a kind of self-identity.

The identity is defined from the multiple interaction and social relation and is deeply marked by social context. Thus, an identity presupposes always a time and a space, while an opposition in relation to other identities. It is, as stated by Berger and Luckmann (1999) and Cabral (2003) for reciprocal recognition between the individual and society that refers to the interdependencies between individual identities and social identities.

\section{Method}

Aiming at a better understanding about the return of Portuguese immigrants from former colonies overseas breaks, this study reconstitution of pathways of life of a group of people, of different ages, who returned to Portugal in the period following the democratic revolution April.

With the "compulsive" return, the general feeling is to be suspended life interrupted, a breach of such a profound way that will require a new beginning in their life journey.

Given these characteristics we think that this study is particularly suitable for analysis based on oral nature, either for its contemporary and accessibility of their sources is its relationship to minority or marginalized groups or by the fact that this methodology allows us to recover a set of memories that, otherwise, would not have access.

It should be emphasized that the Oral History, is both a research method and the basis for the creation of historical sources from the interviews.

The statement does not reflect an easy process but it is true that, due resistances and preconceptions of traditional historiography, oral history has achieved increasing importance worldwide.

It should also be noted that, on the one hand, its production oral history necessarily presupposes historical reflection that lies in the dichotomy interviewer / interviewee. Moreover, oral history can and should be supplemented by other sources. These equation supplies oral / written sources can allow access to a collection of information that otherwise would not be accessible or at least would not be identifiable and / or unintelligible.

But, accepting the importance of oral history, whether it takes the form of thematic history or life stories (or both because they do not mutually exclude) implies accepting a supposed subjectivity and fragility resulting from individual memory. This subjectivity however does not mean that the oral historiography dispense inherent to the work of the subject of knowledge in general procedures: search accuracy and closer to the truth. In addition, there is a whole prior work seeking knowledge of the themes, through all available sources, selection of informants and the themes and contents to be addressed in order to produce documents that will allow us access to different experiences and points of view.

Perhaps because of this, there is someone who presents oral history as "another story" either by its innovative nature or by the special attention it tends to give the "dominated" the silenced or excluded.

Another interesting aspect that arises from oral history, including stories of life, is that legal perspectives give rise to individual pathways that later in many cases, allow for the identification of common points, creating new networks of collective identity here, the group.

According to Bourdieu (2002), is this individual that gives cohesion to the stories of life and so it is also a central element in the production of narratives that result from life stories (which, however, for that author are mainly a result of the social context in issue - the habitus). 
The use of stories life in this study, also in the belief that the testimonies of people about how they face or faced certain questions allow us to identify and better understand possible intergenerational differences.

The interviews were semi-structured, were held to four individuals, two female and two male, who returned from overseas ex-colonies after April 25, 1974. What are the experiences we seek to reflect these particular subjects and how these experiences translate, or not differences in how, forty years later, they see the process of (re) integration in the Metropolis.

To this objective, the interviews were recorded on audio-visual support, fully transcribed and subjected to content analysis. Authorizations for the use of such testimony were requested.

\section{Results}

After the adoption of a set of procedures: a brief description of each case definition of categories and subcategories, definition of thematic structure (for easy comparison), analysis of certain passages considered fundamental, built up the table that follows presents with in order to clarify the results obtained from the life stories analysed.

\section{Interview 1}

Male, resident in Lisbon. Married, with two children and two grandchildren.

Lived several years in Angola (the wife was a native of that country) worked there several years.

Returning to Portugal felt the stigma of "returned". "The population was injected ... as if we've been ruthlessly exploit those people." "Environment was cut with a knife ... until the very land where I was born ... I knew all those people. Like we're all about ... whatever. "(...) People were injected with a hatred tremendous note that today."

For all this believes that "the word "returned" has a pejorative sense and never ceased to have.

In Angola he intended to create a life plan. Until some point "thought it was possible to continue to live in Angola even with Independence

Perhaps this fact has reinforced a certain sense of identity: "My answer would be the same as many others" (...) "identity yes, I can ... the attitude of those who came from overseas is quite different from what they were always here. And we note that even in the day-to-day. "(...) "Solidarity among us also exist." "We were contaminated by the very way of being of the African people ... informal way to receive others, less fatalistic ... more optimistically least fado.

\section{Interview 2}

Female, 59, is the wife of respondent 1. Native of Angola, "fifth generation". States that "never imagined stop living in Angola" as in child thought "never marry a Portuguese."

The return to Portugal was interspersed with a stay of eight years in Brazil where two children were born.

Initially returned "to Portugal because it was here that I had my roots."

Stresses throughout his speech the social relationships in Africa in particular with African who worked at the residence of his parents and in his "beyond a person that worked for us was also a friend ... I was godmother of his children."

It was "a society created over centuries and that had nothing to do with any operation ... was a single company."

On returning to Portugal stigma is still present and once again associated with the term "returned". This term "was a horror ... In the land of my husband I say that today is my land ... even some family, we were ... we were the ones explorers returned. So that I was pregnant, I was 22, even had chances to stay, and I refused to stay here. I went to Brazil where, in fact, no one ever treated me like that. "(...)" It shocked me. "

\section{Interview 3}

Male, residing in Port reformed. 
Went to Africa in 1945. "Went with my dad and my older brother" (...) "when I came here, I felt I had abandoned it, because it was very bad. We had just come out of a war (1945), the living conditions were very bad here. "

Returned to Portugal 47 years old and with the feeling that "the best years of life were spent at the service of Angola".

In Portugal, would hit on every door in search of employment. Age was faced with an obstacle. "47 years, Oh! If you had $35 "$.

The professional integration by the intervention of a family.

Once again, the stigma is still present. Although naturally begin to react to the term "returned", "a term that was attributed to the Portuguese who were forced to return to the country. Never cared much, "ends by noting that" I was shocked when I often drove to the IARN and those individuals who have nothing at the time and had nothing of her, when they saw such men returned to address themselves to the IARN always said: ate what was the black now come to eat what is ours. That's what provoked me. At that time I was mortally wounded and still heard a saying of these. "

Reintegration was not exactly peaceful. "When I came here on vacation was pretty much everything and everybody knew me, had a car, gave a ride to this and to that but when the time came, few if any knew me." (...) "I had to get me alone.

\section{Interview 4}

Female, 80 years, wife of respondent 3. With the fourth grade, became "dressmaker to 16 years.". Went to Angola, after the wedding, to meet her husband.

"I did not know Angola, went over to see what was ... really enjoyed that, let me really miss."

The integration was easy "I felt integrated. There are good people ". "If it was good we had never been away."

Social relations, upon return, (valued at more significantly interviews) were not easy. "Women have not helped, it was bad very bad, thought we needed nothing. I had to start a new life alone. "

The stigma, as in the other respondents, appears associated with the term "returned". "That was the worst thing that could have happened. They thought we walked there to enslave blacks and I never did it. "

"I there treated them very well; I even put my daughter in a college with my washerwoman's daughter to study."

\section{Analysis categories}

The construction of categories and subcategories, taking into account principles of content analysis in the style of Bardin (1977), was based on one side script or screenplay that was based on interviews and on the other objectives of the study now is shown.

Thus, we construct three classes of 3rd order ("Family structure and lifestyle of this"; "before departure" and "return"), seven 2nd order ("family structure", "style and living conditions" , "feelings", "expectations and perceptions", "feelings", "perceptions in return" and "strategies of adaptation and (re) integration") and 15 of 1st order ("Composition of household", "place of residence", "social and professional context", "Degree of schooling", "general feeling", "Expectations", "Vision of the country of origin", "Memories", "general feeling", "perceived Quality of life", "Stigma" , "Relationship of identity," "social interaction" and "socio-professional integration.")

The order assigned to the categories of the general (3rd order) to the specific (1st order).

The respective results and inferences are summarized in the table 1.

\section{Discussion}

The project of democratic society would ideally integrate its members as citizens, promoting their integration and socialization and avoiding any situation of exclusion or marginalization.

However, the process that characterized the period, as is evident by the analysis of the different interviewees, is far from corresponding to this democratic ideal (Schnapper, 2007).

Analysis of the interviews that make up the base of this study seem to stand out a set of common elements. These can be understood as such a group identity to which we referred earlier. The sense of loss, memories of an Africa where it was possible to live in community, the stigma associated with the "return", all brand interviews analysed. 
However, you can find some different points. These can result in age or schooling or even the gender of the respondent.

In fact, for example, in regard to female interviewees always seem to stand out aspects related to social relations (and in other space) while the respondents were male attention seems to turn mainly to issues economic and political nature.

This study represents only part of the interviews already conducted and a portion of the information collected from each of the respondents. This fact, incidentally reflected in the documentary accompanying the study serves ultimately to enhance the wealth and the potential offered by this type of methodology that draws on the stories of life as invaluable source of knowledge.

\section{References}

Abric, J.C. (2000). A abordagem estrutural das Representações Sociais. In: MOREIRA, A. SP; OLIVEIRA, D.C. (org.). Estudos Interdisciplinares de representação social.2.ed.Goiânia:AB,p.27-37.

Almeida, Carlos; Barreto, António Krieger, Line e Petitat,André. (11976). L'Émigration Portugaise (1957-1966). Genebra. (ciclostilado).

Bardin, Laurence. (1977). Análise de conteúdo. Lisboa: Edições 70, 1977.

Berger, Peter L. \& Luckmann, Thomas. (1999). A construção Social da Realidade. EditoraVozes. Petrópolis, 1999 - 17a.ed.

Bourdieu, Pierre. (2002). Entrevistado por Maria Anéa de Loyola. Rio de Janeiro: EDUERJ.

Cabral, M.V.. (2003). "O Exercício da Cidadania Política em Perspectiva Histórica (Portugal e Brasil)". Revista Brasileira de Ciências Sociais, vol. 18, n 51, pp. 31-60.

Chiswick, Barry R.; Miller, Y. L. L. e P. W. (2002) "Longitudinal Analysis of Immigrant Occupational Mobility: A Test of the Immigrant Assimilation Hypothesis", International Migration Review.

Duverger, Maurice. (1994). A Europa dos Cidadãos. Lisboa: Edições Asa.

Lubkemann, Stephen C.. (2003). "The moral economy of Portuguese postcolonial return".in Diaspora, 11 (2): 189-213.

Moscovici, S. (2001). Das representações coletivas às representações sociais. In: JODELET, D. (org.) Representações Sociais. Rio de Janeiro: EDUERJ..45-66p.

Pires, Rui Pena (2003), Migrações e Integração. Oeiras: Celta Editora.

Pires, Rui Pena. (1999). "Uma teoria dos processos de integração". Sociologia, Problemas e práticas, nº 30.

Pires, Rui Pena. (1984). "Os retornados: um estudo sociográfico". Cadernos I.E.D. Lisboa: IED.

Rocha-Trindade, Maria. (1995). Sociologia das Migrações, Lisboa: Universidade Aberta.

Schnapper, Dominique. (2007). Qu'est-ce que c'est l'intégration? Paris: Gallimard. 
Table 1 - Transcriptions of the interviews

\begin{tabular}{|c|c|c|c|c|c|c|}
\hline \multirow{2}{*}{ 3rd order Categories } & \multirow{2}{*}{ 2nd order Categories } & \multirow{2}{*}{ Ist order Categories } & \multicolumn{2}{|c|}{ Transeriptions } & \multirow[b]{2}{*}{ Interview 3} & \multirow[b]{2}{*}{ Interview 4} \\
\hline & & & Interview 1 & Interview 2 & & \\
\hline \multirow[b]{2}{*}{$\begin{array}{l}\text { Family structure and } \\
\text { lifestyle at present }\end{array}$} & Family structure & Composition of household & $\begin{array}{l}\text { Female, two children and two } \\
\text { grandchildren }\end{array}$ & $\begin{array}{l}\text { Male, two children and two } \\
\text { grandchildren }\end{array}$ & $\begin{array}{l}\text { Woman, two children and two } \\
\text { grandchildren }\end{array}$ & $\begin{array}{l}\text { Male, two children and two } \\
\text { gandchildren }\end{array}$ \\
\hline & Lifestyle & $\begin{array}{l}\text { Place of residence } \\
\text { Social and profissional contert } \\
\text { Scholarship level }\end{array}$ & $\begin{array}{l}\text { Lisbon } \\
\text { Stable } \\
\text { University }\end{array}$ & \begin{tabular}{|l} 
Lisbon \\
Stable \\
University
\end{tabular} & Stable & $\begin{array}{l}\text { Porto } \\
\text { Stable } \\
\text { 4th grade }\end{array}$ \\
\hline \multirow[b]{2}{*}{ Before leaving } & Feelings & General feeling & Willingress to study agronomy & Have lived in Angola & $\begin{array}{l}\text { Abandonment and sadness for } \\
\text { leaving Portugal but expectation } \\
\text { for better living conditions }\end{array}$ & $\begin{array}{l}\text { Ansiety join her husband who } \\
\text { was working in Angola }\end{array}$ \\
\hline & \begin{tabular}{|l|} 
Expectations and \\
perceptions
\end{tabular} & $\begin{array}{l}\text { Expetations } \\
\text { Origin country image }\end{array}$ & $\begin{array}{l}\text { Build a life project } \\
\text { Positive }\end{array}$ & Follow with life & $\begin{array}{l}\text { Demand for better living } \\
\text { conditions } \\
\text { Bad conditions aggravated by waas } \\
(1945)\end{array}$ & $\begin{array}{l}\begin{array}{l}\text { To meet the husband } \\
\text { (newlyweds) }\end{array} \\
\text { ( }\end{array}$ \\
\hline \multirow{6}{*}{ The return } & Feelings & $\begin{array}{l}\text { Remembrance } \\
\text { General feeling }\end{array}$ & $\begin{array}{l}\text { Afica: lifestyle and relationship } \\
\text { with the Afyican people. Of } \\
\text { Portugal at that time: } \\
\text { nationalization, prisons, injustice, } \\
\text { hostile environment. } \\
\text { Loss, desire to remain in Afica }\end{array}$ & $\begin{array}{l}\text { Africa: lifestyle and relationship } \\
\text { with the Afican people. In } \\
\text { Portugal hostile environment for } \\
\text { the "retumees". } \\
\text { Loss }\end{array}$ & $\begin{array}{l}\text { Afica: lifestyle and relationship } \\
\text { with the Afican people. In } \\
\text { Portugal: hostile environment for } \\
\text { the "retumees". } \\
\text { Loss }\end{array}$ & $\begin{array}{l}\text { Africa: lifestyle and relationship } \\
\text { with the African people. In } \\
\text { Portugal: hostile environment for } \\
\text { the "retumees". } \\
\text { Loss }\end{array}$ \\
\hline & \multirow[b]{2}{*}{ Perceptions } & perceved life quality & $\begin{array}{l}\text { Initial phase: the need to rebuild a } \\
\text { life project. }\end{array}$ & $\begin{array}{l}\text { Initial phase: the need to rebuild a } \\
\text { life project. }\end{array}$ & $\begin{array}{l}\text { Initial phase: the need to rebuild } \\
\text { a life project lack of support }\end{array}$ & $\begin{array}{l}\text { Initial phase: the need to rebuild a } \\
\text { life project lack of support }\end{array}$ \\
\hline & & Stigma & $\begin{array}{l}\text { "The returned" as someone who } \\
\text { has enriched exploiting Aficans. }\end{array}$ & $\begin{array}{l}\text { The retunned" as someone who } \\
\text { has enriched exploiting Africans. }\end{array}$ & $\begin{array}{l}\text { "The retumed" as someone who } \\
\text { has enriched exploiting Africans. }\end{array}$ & $\begin{array}{l}\text {-The returned" as someone who } \\
\text { has enriched exploiting Africans. }\end{array}$ \\
\hline & \multirow{3}{*}{$\begin{array}{l}\text { Adaptation and } \\
\text { (re)Integration strategies }\end{array}$} & Identity relantionship & $\begin{array}{l}\text { Solidarity pairs similarity of } \\
\text { thoughts and way of being. }\end{array}$ & & & \multirow{3}{*}{$\begin{array}{l}\text { Early stage in Portugal: difficult. } \\
\text { Helps underscore member of the } \\
\text { family resident in Portugal }\end{array}$} \\
\hline & & Social interaction & $\begin{array}{l}\text { Early stage in Portugal: Difficult } \\
\text { Brazil: Cozy }\end{array}$ & $\begin{array}{l}\text { Early stage in Portugal: Difficult } \\
\text { Brazil: Cozy }\end{array}$ & $\begin{array}{l}\text { Early stage in Portugal: difficult. } \\
\text { Helps underscore member of the } \\
\text { family resident in Portugal }\end{array}$ & \\
\hline & & Socioprofissional integration & $\begin{array}{l}\text { Relatively easy (kept the } \\
\text { connection to the same group). }\end{array}$ & 1 & $\begin{array}{l}\text { Difficult Once again underines } \\
\text { the help of a family member. }\end{array}$ & \\
\hline
\end{tabular}

(Designer's note : please increase the view size to see the data) 